\title{
Unequal Interdependency: Chinese Petty Entrepreneurs and Zimbabwean Migrant Labourers
}

\author{
YING-YING TIFFANY LIU \\ Carleton University, Canada
}

\begin{abstract}
Exploring the cultural politics of diasporic entrepreneurs and migrant labourers through an examination of Chinese restaurants in Johannesburg, this article presents what I call the "intra-migrant economy" amid everyday racialized insecurities in urban South Africa. I use the term "intra-migrant economy" to refer to the employment of one group of migrants (Zimbabwean migrant workers) by another group of migrants (Chinese petty capitalists) as an economic strategy outside the mainstream labour market. These two groups of migrants work in the same industry, live in the same city, and have established a sort of unequal employment relation that can be hierarchical and interdependent at once. Chinese migrants are socially marginalized but not economically underprivileged, which stands in contrast to Zimbabwean migrants, who remain economically underprivileged even though they speak local languages. Their different socioeconomic positions in South Africa are profoundly influenced by their nationality and racialization. This analysis of their interdependency focuses on the economic and political structures that shaped the underlying conditions that brought Chinese and Zimbabwean migrants to work together in South Africa.
\end{abstract}

KEYWORDS Migrant entrepreneurship; labour migration; petty capitalism; Chinese diaspora; Zimbabwean diaspora; South Africa

Alice was late when I went to pick her up in Hillbrow, located in the inner city of Johannesburg, for our first interview. ${ }^{1}$ I first met her at the Silver City Chinese restaurant in one of Johannesburg's upper-middle-class

\footnotetext{
${ }^{1}$ All names of people and restaurants are pseudonyms. Detailed locations of the restaurants and participants' hometowns are not provided to protect their privacy; instead, I use broad markers such as "an upper-middle-class neighbourhood in Johannesburg" or "a rural town in Guangdong," with the exception of certain areas in Johannesburg such as Hillbrow and Cyrildene.
} 
suburbs, where I was conducting fieldwork in 2015. As I sat inside my car waiting for Alice, I looked at my surroundings. Hillbrow is not a neighbourhood that I - or anyone who is not part of certain segments of the migrant working class -would usually go to in Johannesburg at that time. An endless stream of cars and minibus taxis made non-stop honking noises in the background. High-rise buildings in ruins gave the appearance of abandonment, but the busy crowd and washed clothes hanging outside of the broken windows suggested residency. Countless street hawkers were selling inexpensive goods, and food items were scattered around crowded and cluttered sidewalks. Most pedestrians did not look like they were from South Africa, but I was probably the only non-black person there.

Hillbrow, once called the New York of Africa, was a glorious symbol of the apartheid regime's prosperity and success (Smith, 2015). Through interviews with Chinese chefs, I learned that two top-of-the-line Chinese restaurants used to be in this formerly whites-only area during the heyday of apartheid. Apartheid is an Afrikaans term that means separateness. It was an institutionalized legal system of racial segregation where the whole population was racially divided in every sphere of life (Yap \& Leong Man, 1996). The system distributed economic wealth and reinforced social privilege along racial lines (van der Berg, 2011). After the official collapse of apartheid in 1994, blacks who had been segregated in townships and homelands were free to move into inner-city areas. ${ }^{2}$ Black people came, and white inhabitants left. Local businesses closed down or relocated to the affluent and predominately white suburbs such as Hyde Park and Sandton in the north, leaving behind a high-rise landscape notorious for its high rates of drugs, theft, violent crimes, prostitution, and poverty. Murder in South Africa has steadily increased as violent crime rates remain high in the country, and Hillbrow is one of the top neighbourhoods for reports of serious crimes (Gous, 2017). Gang members have "occupied" or "hijacked" buildings and then collected income by renting out space to foreign-born African residents who cannot afford a self-contained unit (Silverman \& Zack, 2008). As such, Hillbrow has been considered a "migrant space" because of its high percentage of African migrant residents, including Zimbabweans (Moyo, 2017).

There have been property and commercial investments to revitalize parts of the downtown over the past ten years (Smith, 2015). Most Chinese migrants do not know about these new developments and changes because they have been warned by other Chinese to not go near "black areas" such as Hillbrow. ${ }^{3}$ But the Chinese are not the only ones with such geopolitical

\footnotetext{
${ }^{2}$ During apartheid (1948-1994), residents were segregated based on racial classifications (Gradin, 2013). Homelands and townships were established for non-white populations. Nowadays, townships are usually underdeveloped urban living areas in South Africa.

${ }^{3}$ I noticed that throughout conference presentations or numerous discussions of my research with scholars from various backgrounds whether in North America, South Africa, or China, different audiences tend to have different reactions towards the term "black" when it is
} 
ideas. On the one hand, to some South Africans, Hillbrow is a shameful reminder of "a First World country turned into Third World," as a white South African said to me when expressing his anger and disappointment with the post-apartheid government. On the other hand, Hillbrow represents a "land of hope" for someone like Alice, a migrant worker from a rural town in Matabeleland North province, Zimbabwe, a country with a high rate of unemployment. ${ }^{4}$ What is interesting is that most Chinese migrants do not share the same vision as African migrants and instead view Hillbrow as a remnant of the "good old days of South Africa" - even though most of them were not on the continent during the apartheid era (1948-1994), and they are not even sure what apartheid was about.

Based on original ethnographic research in Johannesburg's Chinese restaurants, this article explores the complex realities of, and relations between, Chinese and Zimbabwean migrants who rely on the restaurant sector in South Africa to economically survive in their new country of residence. Generally speaking, Chinese restaurants in Johannesburg share three striking features. First, it is common to find one Chinese chef managing three to five black helpers, the majority of whom are not from South Africa. Second, Chinese employees' wages are at least three times higher than those of black employees, and the number of black employees usually exceeds the number of Chinese ones. Third, this form of restaurant entrepreneurship operates without legal contracts to bond employers and employees. I met kitchen staff, shelf stockers, shopkeepers (who worked at Chinese-owned shops or restaurants) from Lesotho, Malawi, and Mozambique, but Zimbabweans constituted the greatest number of workers from an African country. This is not surprising considering that Zimbabwean migrants make up the largest foreign national group in South Africa (Moyo, 2017).

Another interesting point is that before coming to South Africa, most of the Chinese restaurant owners had no experience operating a business, and none of the Zimbabwean employees had ever worked for Chinese people. In addition, for more than half of the Zimbabwean interviewees I spoke with, working in the Chinese restaurants was their first employment. These features made Chinese restaurants in Johannesburg a natural space in which to understand the relationship between Chinese and Zimbabweans in South Africa - two groups of migrants who are linguistically and culturally different but bound to work together in order to make ends meet. I call their binding "interdependency," although it is not always a happy one.

associated with people's skin colour. As one of the anonymous reviewers suggested, the term "black" needs to be unpacked and requires more elaboration. While the phenomenon of different reactions is interesting in itself, due to space limitations, I will only elaborate on the usage of "black" to reflect my Chinese interlocutors' perspectives in this paper.

${ }^{4}$ Estimates of Zimbabwe's unemployment rate range wildly. According to ZIMSTAT, Zimbabwe's national statistics agency, the country's national unemployment rate was $6.6 \%$ in 2017 (Makichi, 2018). Others argue that it is as high as 95\% (BBC Reality Check team, 2017). 
In this article, I present the idea of "intra-migrant economy," a term I use to refer to the employment of one or more groups of migrants by another group of migrants as an economic strategy outside the mainstream labour market. The terms "immigrant economy" (Siu, 1987) and "ethnic entrepreneurs" (Smart, 2003) refer to a minority ethnic group in a host country that tends to occupy certain types of sectors. Building on these concepts, which have been developed in order to understand the relationship between diaspora and entrepreneurship, I introduce the intramigrant economy to explore deeper questions beyond who has moved and why. What were the economic and political structures in the host country that shaped the underlying conditions that created economic differentiation between, in this case, Zimbabweans who make significantly less than Chinese migrants even though their education levels and local language skills are higher than those of their Chinese co-workers? By examining how Chinese and Zimbabwean migrants have been positioned in South Africa's racialized market, I explain the persistence of the current racial wage gap despite some progress since the end of apartheid over two decades ago.

Although I use the term "interdependency" to describe a mutual dependence between Chinese employers and Zimbabwean employees where Chinese can avoid hiring South Africans and maximize profits from cheap Zimbabwean labourers, while Zimbabweans can easily obtain jobs without following proper procedure or having already developed employment skills - I do not suggest it is a fair or equal one. To explore the Chinese and Zimbabwean employment relationship further, I draw on the argument of anthropologist Hannah Appel (2018) who suggests that instead of focusing on how the current capital market operates as a structure that enlarged inequality, we should first understand that the market is in fact made by that inequality, and nationality and race can be often be the essential form of labour organization.

While I point out that the social reality of South Africa's racialized income inequality created the economic differentiation that leads Zimbabweans to earn significantly less than the Chinese, I also suggest that we should pay attention to what leads two groups of migrants to work together. Often this occurs through different precarious circumstances but equally uneven economic globalization. Although there are often social justice initiatives to promote the rights of immigrants and end their labour exploitation, my analysis of the intra-migrant economy suggests such initiatives need to better understand the circumstances of different immigrant communities and what they really need, in order to respond appropriately to their situations. 


\section{People Involved in South Africa's Chinese Restaurant Entrepreneurship}

The exact number of Chinese in South Africa is impossible to verify due to a large number of non-registered Chinese migrants; moreover, South Africa's Home Affairs officials keep poor records (Park \& Chen, 2009; Harrison, Moyo, \& Yang, 2012). We can only estimate that there are about 350,000 to 450,000 Chinese migrants, most of whom arrived in South Africa after 1990 (Park, 2009; Chen, 2013). Of the newly arrived Chinese migrants, about one-third (around 100,000) are from Fujian province. Migrants from Guangdong are the second-most numerous (Chen, 2013). As I have pointed out elsewhere (Liu, 2017), guanxi - often understood as Chinese social networking - is particularly essential in shaping Chinese migrants' economic activities and opportunities in South Africa. As a result, Cantonese-speaking people tend to dominate the Chinese restaurant sector due to migrant networks, as a large number of chef and server positions at Chinese restaurants are filled by Cantonese-speaking employees.

The size of the Zimbabwean population in South Africa, like the Chinese one, is impossible to pin down. There has been much debate about the number of Zimbabwean migrants in South Africa, and estimates have ranged from 1.5 to 4 million (Crush \& Tevera, 2010). Nevertheless, it is generally agreed that Zimbabwean migrants constitute the largest foreign national group in South Africa (Moyo, 2017). Similar to my findings on Chinese migrant networks, Khangelani Moyo's (2017) data based on 150 Zimbabweans living in Johannesburg also demonstrates the importance of the Zimbabwean migrant networking system. Moyo argues that social networks play an important role in shaping Zimbabwean migrants' access to accommodation and employment opportunities, especially upon their initial arrival.

My observations aligned with Moyo's argument, as the majority of Zimbabweans (23 out of 26) I interviewed, including Alice, were Ndebelespeaking people from the southwestern part of Zimbabwe. Among them, 20 had received help from family members or friends when they first moved to Johannesburg. My data also shows that 15 of them got their jobs in Chinese restaurants through a family member or friend who had worked there. The remainder followed others' advice in seeking employment opportunities with the Chinese. Describing how she found her first job, one Zimbabwean interviewee said, "People told me to just go to Chinatown or any Chinese restaurant and ask every Chinese person if they are hiring. If they need people, they hire you right away." Most importantly, she noted, "Chinese don't check ID." 


\section{Research Methods, Ethics, and Some Reflections}

This original ethnographic research was conducted in Johannesburg over 14 months, from November 2014 to November 2015 and from July 2016 to September 2016. A mixed-methods research approach was deployed. First, I used participant observation: I worked part-time voluntarily at five Chinese restaurants in different neighbourhoods across Johannesburg. ${ }^{5}$ I made sure the restaurant owners and employees were clear that I was there as a learner and observer. In order to minimize my impact on other staff by never reaching a point where I would take over someone's job, I did not work at the same restaurant for more than two months. This level of engagement allowed me to gain first-hand insight into their restaurant life. I call it "restaurant life" because of the long working hours (at least nine hours a day, six days a week, and even longer for restaurant owners) and because many Chinese employees also live with their employers.

Second, I engaged in archival research: I collected restaurant menus, photographs, advertising posts, online and hardcopy Chinese- and Englishlanguage news articles, and news from social media (e.g., WeChat) to gain access to the discursive context of relevant social practices and relations.

Third, I conducted unstructured and semi-structured interviews: I interviewed 40 Chinese employers and employees (22 men and 18 women) in person during 2015. I also interviewed 26 Zimbabwean employees (21 women and five men), some in 2015 during my first round of fieldwork but most in 2016 during my second round of fieldwork. The working relationship between Chinese and Zimbabwean migrants can be tense. ${ }^{6}$ In addition, some restaurant owners did not want me to interview their employees, either Chinese or Zimbabwean, because they worried I would disturb their workflow and productivity. Due to research ethics, I did not actively recruit Zimbabwean participants while doing research inside the restaurant where they worked. When I returned to South Africa in 2016 for three months, I revisited some Chinese participants, but I primarily spent my time recruiting and interviewing Zimbabwean employees. I hired Tichaona Makambwa, who is fluent in isiNdebele, chiShona, and English, to assist me in recruiting Zimbabwean restaurant workers. Tichaona joined a few interviews and helped to translate them afterwards. Most of the Zimbabwean workers in Chinese restaurants were women due to the gendered division of labour. I interviewed (or re-interviewed) more than half of the Zimbabwean women participants alone in order to pay closer attention to gender dynamics. I conducted all of the interviews with

\footnotetext{
${ }^{5}$ Three restaurant owners cooked good meals to show their appreciation of my voluntary work, and two other owners paid me afterwards.

${ }^{6}$ This is not meant to indicate that Chinese employers and employees had a smooth working relationship. In a previous article (Liu, 2018), I argue that there is always conflict due to the nature of the employer-employee relationship; however, it is even more evident between two groups of people who are linguistically and culturally different.
} 
Chinese participants in Mandarin or Cantonese and translated them myself. The transcribed interview data with both Chinese and Zimbabwean participants have been edited for the purpose of confidentiality.

It is also worth mentioning that translation is not easy, especially between two languages that have very distinctive grammatical and sentence structures. Another difficulty is in translating slang related to race, such as the word "black" (黑 hei). Chinese people like to add "black" in front of terms that are associated with black people - for instance, black worker (黑 工 heigong), black woman (黑婆 heipo), black area (黑人区 heirenqu), and black bus (黑巴 heiba). ${ }^{7}$ During the early stage of my fieldwork, I found these terms offensive because they were generally associated with places or things with negative connotations in the South African context, such as unsafe areas or dirty and crowded buses. Later, when I began to interview Chinese participants individually, I realized they did not know any other term to describe black African workers, and they were not aware of the negative implications of their words. When I used more neutral terms (e.g., "Zimbabwean migrant workers" or "kitchen helpers") in my questions, many Chinese interviewees had no idea who I was referring to. Even when they were describing Zimbabwean people positively, they still used "black woman" or "black worker." When I asked the Chinese interviewees where these terms came from, they simply replied, "I don't know. I just follow what other Chinese people call them."

After having been called "Oriental" by South Africans of European descent (who meant it in a positive way) several times, I began to reflect on my experiences in North America, where the word "black" is often substituted with "African American" or "African Canadian" and, similarly, the term "Asian" is used instead of "Oriental." These replacements are considered to be less offensive and more politically correct. People in other parts of the world might not understand the discriminatory meanings behind what we in North America perceive as inappropriate racial terms. As such, where Chinese interviewees used the word "black," I have translated it literally without negative connotations.

\section{Inside the Restaurants}

Alice knocked on the window of the car. I almost did not recognize her because she was in a different style of outfit. She was thrilled that I had noticed her new jeans and said, "I bought this pair three months ago. Finally, a chance to wear them out!" Alice spent eleven hours a day, six days a week, at her workplace and one and a half hours per day commuting between work and home. She rarely had time to go out. "We should go

\footnotetext{
7 "Black bus" or heiba, is a term for a minibus taxi, which is the most popular and affordable form of transportation for working-class people in South Africa.
} 
somewhere else, you know, like where the Silver City is, or the place near the Indian family's house," Alice suggested. Before being employed at Silver City, she was a domestic worker for an Indian family in an uppermiddle-class suburb of Johannesburg. It was her first job after moving to South Africa in 2013. The Indian family paid her R25 a day for working five hours and provided one meal, but she had to spend R23 a day on transportation. "It was a joke," Alice said with a dry laugh. "I earned nothing, but that was the only thing I could get. Two months later Silver City needed more people so my sister took me to see Madam." $" 9$

Alice was in her mid-20s and had not found any job after graduating from her GCE Ordinary Level in secondary school in Zimbabwe (roughly equivalent to grade 11 in Canada). She left her two-year-old son to be raised by her sister at home, and joined her two other sisters - who had left Zimbabwe for the same reason - in Johannesburg. Another sister of Alice's sister was the first one in the family who had come to Johannesburg, and she worked at Silver City. That sister helped Alice's sister to get work there. Knowing that her employers, Mr. and Mrs. Hong, preferred to hire migrants, the first sister introduced the second sister to them, as the second sister introduced Alice later on. Ever since, Alice had worked at Silver City from 10:30 a.m. to 9:30 p.m., with a two-hour lunch break, six days a week. Her starting salary was R85 a day and paid in cash once a month. No tips. No benefits. No contract. No insurance.

On Alice's recommendation, I drove us to a coffee shop in a predominately white neighbourhood, where a coffee and cookie plus tip would cost more than half of her daily wage (raised to R90 after one year of work, then R100 after three years). Alice began the conversation about her job by talking about communication problems, as Mr. and Mrs. Hong had bad tempers and lacked proficiency in English: "Boss and Madam always say that we [Zimbabweans] don't listen to them or we don't understand English. But they are the ones with bad English. Not us!" Alice continued to talk about employment issues:

Boss and Madam are too cheap. When it gets too busy, Madam tells us to help the Chinese to deliver food to customers, clean tables, and bring dishes into the kitchen. Madam also warns us not to talk to customers because she thinks that we will ask for tips. She always says she will share tips with us at the end of the month, but never once has! Boss and Madam don't allow us to eat restaurant food, even customers' leftovers. I'm at work all day long. When I get home it's almost 10:30 every night. I'm too tired to cook.

\footnotetext{
${ }^{8}$ The exchange rate from the Canadian Dollar to South African Rand is usually around 1 CAD to $10 \mathrm{ZAR}$. The currency symbol of the rand is R.

${ }^{9}$ Alice and other Zimbabwean staff addressed the female owner of the Silver City restaurant as "Madam," and the male owner as "Boss." Other Zimbabwean staff usually called female owners "Lady Boss" or just their names.
} 
It is important to note that Mrs. Hong was probably the least generous Chinese employer - to both Chinese and African staff - I met throughout my fieldwork in Johannesburg. Two former Chinese employees also told me that Mrs. Hong cheated them out of tips. At the five Chinese restaurants where I did research, two provided meals for African staff, two did not (including Silver City), and in the fifth one, the African employees usually cooked their own meals and were also free to use some food products from the restaurant.

In fact, Alice was the highest paid kitchen helper I met. The monthly income of the Zimbabwean workers I interviewed was in the range of $\mathrm{R} 1,700$ to R2,200; Alice made R3,000. Some of the Zimbabwean newcomers had even accepted a starting salary as low as R1,400, just as Alice had done with her first low-paying domestic worker job. This was not the case for the Chinese migrant workers. Both Chinese and African employees work nine to 11 hours a day, six days a week, but Chinese employees' wages are at least three times higher than those of black employees. Before continuing the discussion on wages, it is important to understand the division of labour inside the Chinese restaurants.

Almost all Chinese take-away restaurants in Johannesburg serve Westernized versions of Chinese food and sushi (and sometimes Thai-style cuisine). As such, they usually offer two sets of menus: one for warm Chinese food and one for freshly made sushi. The jobs that require more specialized skills, like cooking Chinese cuisine and making sushi, are performed by Chinese men. Service and cashier jobs are mostly performed by Chinese women. Many medium-sized restaurants that cater to South African clientele have a combination of Chinese waiters (usually in manager positions), Chinese waitresses, and black African waiters and waitresses. African servers usually serve non-Chinese customers, while Chinese servers are for Chinese customers.

Regardless of the size of the restaurant, the total number of black employees usually exceeds the number of Chinese ones. Lower-skilled jobs - including but not limited to washing dishes, chopping vegetables, cutting meats, cleaning pots and floors, preparing ingredients (e.g., wrapping dumplings), and making simple items (e.g., sauces) - are all performed by black employees. In a typical Chinese take-away restaurant run by a Chinese couple, the wife works at the front counter to take orders, answer phone calls, and process payments, while the husband works as the cook chef or sushi chef. The black employees do everything else from cleaning to packing. The take-away restaurants I visited all employed at least four African kitchen workers but no more than one cooking or sushi chef, because it would be too costly to hire another. As the chef's salary usually took up a large percentage of operating costs, every small- to medium-sized restaurant owner that I interviewed was the chef of their own restaurants in order to reduce payroll costs and avoid the problem of shortages of trained chefs. More and more Chinese owners/chefs have been training, or starting 
to train, African employees to cook simple items (e.g., spring rolls) in order to reduce their own working time. This strategy is a result, in part, of the weakening South African currency, which has affected the recruitment of Chinese employees in South Africa and from China. By the end of my fieldwork (September 2016), as the value of the rand continued to fall, fewer Chinese migrants were coming to South Africa, and more and more Chinese immigrants were talking about leaving South Africa (also see Kuo, 2017).

Most restaurant owners I interviewed had worked at other restaurants for a few years until they had saved up some capital to open their own restaurants. Mrs. Hong was no exception. It is worth examining Mrs. Hong's story in order to understand the challenges most small- and medium-sized Chinese restaurant owners face as petty capitalists in South Africa. Anthropologists Alan Smart and Josephine Smart (2005, p. 3) define petty capitalists as "individuals or households who employ a small number of workers but are themselves actively involved in the labor process." They argue there is a need to distinguish between "entrepreneur" and "petty capitalist," and there is a difference between multinational corporation entrepreneurship and small-scale entrepreneurship with little capital, like the restaurant owners in this research.

Mrs. Hong and her husband moved to South Africa in the mid-1990s. After having worked at other Chinese restaurants for some years they had some savings. Combined with money borrowed from family, they finally had enough capital to open their own restaurant. The most common way of owning a restaurant is buying an existing business, since the equipment, name, and menu are already there. The Hongs took over a restaurant from another Chinese couple. Like any typical family-run Chinese restaurant, Mrs. Hong works on the floor as a server and cashier, and Mr. Hong cooks in the kitchen along with three South African helpers.

One day Mrs. Hong found out that one of the employees was stealing food products. She gave a warning. The employee reported this conflict to the union. Later, Mrs. Hong caught the other two employees stealing kitchen equipment. She phoned the police. The police came to the restaurant, asked for information, wrote a report, and arrested the two employees. When Mr. and Mrs. Hong went home the next night, they found these two employees and police inside their house. They were assaulted and had their cash taken by them. Mrs. Hong was still very angry about this incident when she described it to me, even though it had happened almost 15 years earlier:

Not only we were mugged, we also lost two employees. That's when I realized Chinese cannot trust black South Africans, especially those dirty cops! I was an optimistic person, I still said to my husband, "That's okay, we can always make more money as long as we're safe. No problem. We can eat bitterness (endure this hardship)." ... Just when I thought things couldn't get any worse, the labour union threatened to shut our business down if we didn't accept the 
demand from the employee who stole food. Everything was so absurd! We paid a lot of money for the employee to go away.

Subsequent to this disturbing experience, Mrs. Hong has not hired South Africans in order to avoid union disputes. She hired Alice's sister and continued to hire people from Alice's extended family. I asked Mrs. Hong about the risk of hiring undocumented workers, as Alice and her sisters did not have proper documentations to work in South Africa. She laughed and said, "cops only come after the Chinese if they want bribes, not because they are serious about crimes. Every Chinese person in this country has to learn how to protect themselves. The police will rob you if the opportunity comes." Not only did she feel that it was safer to have foreign workers around, she thought it was easier to manage them. "Migrant workers are more innocent and obedient," Mrs. Hong explained. "And they are willing to work harder for less money. But they also steal. All blacks steal. It's only a matter of different degrees of values. At least migrants appreciate that I provide them stable jobs."

Two points are worth noting here. First, Mrs. Hong caught Alice eating rice and leftover food several times. But to Alice, not only did the long work hours and commute time take away from her time to shop and cook, ${ }^{10}$ but also she was just eating something she felt was not valuable. Alice did not see the "theft" that Mrs. Hong claimed she had committed. I also interpret Alice's eating of leftovers as a form of resistance against exploitation and Mrs. Hong, who had failed to share tips as promised. ${ }^{11}$ Mrs. Hong is not the only Chinese employer who believes that "all blacks steal," even though there are often contradictions and misconceptions in this message. For instance, there have been cases of theft committed by Chinese employees, but those were less likely to be publicly discussed within the Chinese community. However, if anything went missing, as several Zimbabwean employees complained during interviews, their Chinese employers often accused them of stealing without giving them a chance to prove their innocence.

Second, Mrs. Hong was not alone in not being concerned about the legal consequences of hiring migrant workers without proper documents and procedures. Quite the contrary, many Chinese employers I met suggested the legal risk of hiring South Africans was higher because then they had to deal with South Africa's labour laws. Furthermore, employers can also avoid taxes when paying their employees under the table; it's an all-cash economy. There are several reasons why many Chinese people prefer not to

\footnotetext{
${ }^{10}$ As noted, Alice lived in Hillbrow because she simply could not afford to live in the neighbourhood where Silver City is located. Every working day, Alice spends one and a half hours on a minibus (share) taxi.

${ }^{11}$ My inspiration for this interpretation comes from Aihwa Ong's first ethnography, Spirits of Resistance and Capitalist Discipline: Factory Women in Malaysia (1987), where she argues that Malay women workers were periodically seized by spirit possession as a way of rebelling against the exploitative working conditions without being punished by the management.
} 
use official banks: language barriers, questionable immigration status, or a desire to avoid state financial regulation. Because it is well-known that Chinese people do business in cash, carry cash around and store large amounts of money at home, they are targeted for violent crime (see Chen, 2013).

When I asked Mrs. Hong about the benefits of employing migrant workers, the first thing she explained, before she talked about wages, was that "migrant workers are more innocent and obedient." Even though Mrs. Hong did not really trust any black person, she had to employ some African workers in order to make the business profitable. In her view, South Africans were more difficult to deal with since they had more resources (e.g., labour unions) and stronger local contacts (e.g., police). She preferred to hire migrants as she could have more control over them, because she knew that her Zimbabwean employees needed the work desperately.

In this section I have outlined why small and medium-sized Chinese restaurants prefer to hire migrant workers and how Zimbabwean migrants find jobs in this sector. The preference for hiring migrants over local workers should not be taken to mean that no Chinese employers hire locals in South Africa. There is no denying that the likelihood of African migrant workers accepting lower pay and longer working hours is an attractive factor for Chinese businesspeople, particularly for petty entrepreneurs who struggle with little capital and limited resources. Lowering costs is certainly an important business strategy, but it is not the sole determining factor in the case of South Africa. The next section explores the relationship between migration and the local market - what I call the intra-migrant economy in the case of Chinese restaurant entrepreneurship in South Africa.

\section{The Intra-Migrant Economy}

As a result of economic crisis and social collapse, the flow of out-migration from Zimbabwe increased massively during the 1990s and has risen again sharply since 2000 (Crush \& Tevera, 2010). Zimbabweans, from all kinds of social and educational backgrounds, skilled professionals and unskilled workers, have left. For instance, more than half of trained medical doctors went abroad in 2000 (Chikanda \& Dodson, 2013). It is estimated that over two million Zimbabweans have left for various destinations (Makina, 2010). As the largest city in South Africa, as well as the one with the most employment opportunities, Johannesburg has become a major destination for Zimbabwean migrants (Moyo, 2017). Semi-skilled and unskilled Zimbabwean migrants from rural areas - e.g., Alice and her sisters - often end up working in the restaurants in Johannesburg, as this is a low-wage, low-skill, and low-barrier-to-entry sector.

My data on Chinese restaurant workers indicate that the majority of them are from rural areas of China, particularly the province of Guangdong, 
where most of them had a limited chance to continue to higher education, as their families could not afford it. In order to contribute to the family earnings, some of them worked on family farms at a young age, or they left their villages and worked in minimum wage jobs in a city. Due to limited social and economic mobility in rural areas of China, their best option for economic improvement is to go abroad, and the best chance to find an overseas job is through their overseas network, including hiring migration agencies (Chu 2010; Xiang 2017). ${ }^{12}$

The majority of Chinese newcomers I spoke to during my research already had at least one relative or close friend living in South Africa prior to their arrival; their lack of English skills or an understanding of the visa application process would have prevented them from applying for South African work permits on their own. Consequently, most Chinese newcomers utilized services provided by Chinese migration agencies to get into South Africa and, in some cases, to find jobs. As Chris Alden notes, many Chinese migrants in South Africa "are pursuing opportunities and have used migrant brokers, both legal and illegal, to obtain the necessary paperwork to immigrate" (in $\mathrm{Xu}, 2007$, p. 52). Liang Xu suggests that in Cyrildene, which is the second Chinatown located in Johannesburg's suburbs, it is possible to find questionable activities anywhere. For instance, "an unassuming photocopy shop can [be] where illegal paperwork such as fraud visas, passports, and driver's licences get traded. A regular travel agency may in fact be an underground money-laundering service provider" (Xu, 2017, p. 88).

The topic of illegality was in the air among the Chinese communities in Johannesburg but not something that was openly discussed in public. Under such uncertain conditions, anyone can be a victim or a participant. Some Chinese interlocutors I talked to admitted that they knew about fraudulent paperwork or did not follow regulations such as those about overstaying in the country on a visiting visa. Many said it was possible they had been the victim of forged documents. In some cases, Chinese migrants did not know that they had paid for invalid work permits until they passed through airport immigration checkpoints and were arrested.

The condition of illegality, whether in relation to Chinese or Zimbabwean migrants, plays an interesting and yet contradictory role. On the one hand, many Chinese migrants, especially those who were not sure if they held a legitimate visa, worried about police asking for identity

\footnotetext{
${ }^{12}$ Due to space limitations, I am unable to provide an in-depth discussion and analysis on migration brokers here. Anthropologist Biao Xiang (2017), who has conducted extensive research among the Chinese rural workers who go work abroad, argues that migration brokers play an important role in facilitating and maintaining migratory flows between China's rural areas and other parts of the world. Anthropologist Julie Chu's ethnography (2010) provides a detailed account showing how people from rural areas of Fuzhou came to the United States with the assistance of migration agencies. In South Africa, I met many Chinese restaurant workers who regularly sent remittances back to China while still paying off loans to the migration agency.
} 
verification. The Chinese Embassy in South Africa and several Chinese organizations have publicly advised overseas Chinese not to break local laws, including laws against hiring undocumented migrant workers. ${ }^{13}$ On the other hand, although people are aware of illegal activity, it is somehow acceptable as it speeds up the migration and recruitment processes. A fast and convenient way of hiring employees, whether from China or Zimbabwe, is particularly important for Chinese restaurant owners, because restaurants in general are labour-intensive.

$\mathrm{Xu}$ (2017) sees this sort of uncertainty within Cyrildene Chinatown, and in Chinese people's relationship with non-Chinese, as a response to the economic and geopolitical restructuring of post-apartheid South Africa. $\mathrm{He}$ writes:

On the one hand, it defies the commonly held neo-liberal predications that once the apartheid is abolished, class lines are supposed to replace racial/ethnic lines in social integration. Apartheid obviously has a resilient afterlife. As wealthy middle class relocate to the northern suburbs, ethnicities do not simply disappear but are reorganising themselves in different forms. On the other hand, Cyrildene Chinatown is also a natural expression of post-apartheid South Africa's trade and immigration policies. Under such policies, large-scale immigration is tolerated. (Xu, 2017, p .91)

I agree with $\mathrm{Xu}$ 's argument that this double process of formality and informality happening in Cyrildene Chinatown is a response to the postapartheid restructuring, and want to further point out that it is also a response to apartheid itself, as racial inequality is still very much a structural problem in South Africa.

Although pay may vary depending on various factors, generally speaking, Zimbabwean kitchen helpers earn R1,500 to R2,700 per month and Zimbabwean chefs earn R3,000 to 5,000, both without any accommodation or transportation. In South Africa, it is common to find Chinese employees living with their employer's family or at a rental flat provided by their employers, along with other employees; likewise, is it common for them to get a ride to work from their employers. There are some exceptions, such as those who prefer to live with their own family or have access to their own vehicles; Chinese employees in these circumstances get their accommodation costs reimbursed. Chinese cooks make R12,000 to 20,000 per month depending on qualification, and Chinese servers make R9,000 to 11,000 or more depending on tips, with both accommodation and transportation provided or subsidized. A Chinese sushi chef's salary is less than a Chinese chef's (a starting salary is R9,000 to 10,000 per month), because making sushi is a relatively easy skill to learn (though not by Japanese standards) compared to cooking Chinese cuisine. The Chinese

\footnotetext{
${ }^{13}$ See, for example a Chinese news article (Song, 2015) that warns Chinese employers that undocumented migrant workers are a potential threat to their safety.
} 
sushi chefs working at non-Chinese-owned sushi bars earn R10,000 to 12,000 a month without any additional benefits.

This issue of large racialized wage inequalities is deeply rooted in South Africa's colonial and apartheid history (van der Berg, 2011; Gradin, 2013). As Carlos Gradin (2013) argues, "South Africa stands out as a country with one of the largest racial divisions in the world due to European colonisation and the apartheid regime that followed independence, which officially ended in $1994 \ldots$ This racial divide has remarkable implications in terms of poverty and deprivation by population group" (p. 187). In order to understand what Gradin means about poverty and racial divisions, we need first to see the most recent data on average incomes from Statistics South Africa (Table 1).

\begin{tabular}{|c|c|c|c|c|}
\hline \multirow[b]{2}{*}{ Income source } & \multicolumn{4}{|c|}{ Census group (percentage of national population) } \\
\hline & $\begin{array}{l}\text { White } \\
(8.9 \%)\end{array}$ & $\begin{array}{l}\text { Indian/Asia } \\
(2.5 \%)\end{array}$ & $\begin{array}{l}\text { Coloured } \\
(8.9 \%)\end{array}$ & $\begin{array}{c}\text { Black } \\
(79.2 \%)\end{array}$ \\
\hline Income from work & 300,498 & 215,784 & 131,699 & 69,094 \\
\hline Income from capital & 16,184 & 2,173 & 1,364 & 842 \\
\hline $\begin{array}{l}\text { Pensions, social insurance, } \\
\text { family allowances }\end{array}$ & 30,739 & 10,028 & 12,260 & 8,921 \\
\hline Income from individuals & 5,232 & 3,309 & 2,430 & 2,194 \\
\hline Other income & 6,520 & 2,323 & 2,265 & 1,261 \\
\hline $\begin{array}{l}\text { Imputed rent on owned } \\
\text { dwelling }\end{array}$ & 85,271 & 38,005 & 22,747 & 10,671 \\
\hline Total & R444,446 & R271,621 & R172,765 & R92,983 \\
\hline Monthly & R37, 037 & $\mathbf{R} 22,635$ & R14,397 & $\mathbf{R} 7,749$ \\
\hline
\end{tabular}

Table 1. Average Annual Income of Household Head by Racial Group in South Africa (Source: Statistics South Africa, 2017, p. 14)

This table is based on data collected from 23,380 households across South Africa over a period of 12 months (2014 to 2015). The data shows that white South Africans earn the highest average incomes at R444,446 per year, which is over one and a half times greater than Indians/Asians at 
R271,621, and almost five times more than black South Africans at R92,893 per year. According to Gradin, white South Africans earned about ten times the average per capita income of blacks in 1993, and about eight times in 2008. Since apartheid ended over 20 years ago, the black upper and middle classes have grown, and "the black share of the richest quintile of the population rose substantially, from 22 per cent in 1993 to 42 per cent in 2008 (though this remains far below their population share)" (van der Berg 2011, p. 128). But as shown in Table 1, the average white South African still earns at least five times more than the average black South African, and the majority of blacks are still economically disadvantaged and relatively insecure because they have fewer assets. Despite the progress made after apartheid, black people face higher poverty and deprivation rates than any other population group. In addition, as Gradin points out, high unemployment rates and high racial segregation across occupations also challenge South Africa's wage economy.

In terms of Chinese migrant workers, as noted, Chinese chefs make R12,000 to 20,000 per month with accommodation and transportation provided. Chinese servers make around R9,000 to 11,000 depending on tips. They are not considered rich, and they have to work more than nine hours a day for six days a week. But in contrast to black South Africans, the majority population in the country, Chinese migrants working at restaurants are definitely not poor. They might even be considered middle class, although they continue to be outside the social mainstream. Thus, I suggest, many Chinese newcomers in South Africa are socially marginalized but not economically underprivileged, which stands in contrast to Zimbabwean migrant workers, who can look or sound like black South Africans (Moyo, 2017) but remain economically underprivileged.

This is where differences in Chinese and Zimbabwean racial and economic positions become apparent, embedded as they are in the framework of (post-)apartheid South Africa. Due to linguistic and cultural barriers as well as business and job opportunities that are largely structured around guanxi relations, Chinese migrants can avoid integration into South African society, but this does not prevent them from getting an average monthly income that is higher than that of black South Africans. If Chinese restaurants owners are able to hire black South African workers for less than R4,000 a month, Zimbabwean migrant workers then have to accept even lower salaries. As noted, many Chinese restaurant owners find benefits to hiring migrants over local workers. Zimbabwean migrants who work under such unfair conditions do so not because of threat of physical force but due to lack of options: they are already in an alternative intramigrant labour market. In other words, despite the often tense and conflictual working relationship between Chinese and Zimbabweans, the Zimbabweans need the Chinese for jobs, and the Chinese need the Zimbabweans for labour. I use the term "interdependency," rather than 
dependence, in order to emphasize that Chinese employers also need Zimbabwean employees in order to survive.

\section{Racialized Interdependency}

The term "interdependency" is used here to describe a mutual dependence between Chinese employers and Zimbabwean employees. Even though mutual benefits flow between Chinese and Zimbabwean actors who are involved in restaurant entrepreneurship in South Africa, this is not an equal or free interdependency. Urban and rural inequality in China is the reason a large number of migrants left rural areas to go abroad and seek economic betterment (Chu 2010; Xiang 2017). Lack of work opportunities in rural areas of Zimbabwe also led migrants to come to South Africa. These two groups were equally vulnerable in their home countries, but through their support networks and cross-border mobility, they were "free" to go abroad in search of better opportunities. Both came to feel equally "unfree" when they found that their best (or only) option in South Africa was to work in the Chinese restaurant sector, which largely operates outside of the legal framework.

As they enter South Africa's racialized labour market, the Chinese eventually find themselves able to climb the ladder to the middle class, while the Zimbabweans continue to struggle with being paid below minimum wage. For instance, any full-time trained Zimbabwean chef still earns less than any part-time or semi-trained Chinese chef; this wage differentiation is embedded in South Africa's racialized labour market, regardless of the amount of time a person has worked or their qualifications. According to Hannah Appel $(2012 ; 2018)$, this is how the market works.

In an online article, "Race Makes Markets: Subcontracting in the Transnational Oil Industry," Appel (2018) points out that nationality is the main way that US oil companies in Equatorial Guinea organize labourers. For instance, US and UK employees usually have the best schedules, while Filipino workers have the least desirable schedules. In contrast, overqualified Equatoguineans have difficulties obtaining a promotion even if they have gained an engineering degree from France and performed well in their jobs. As Appel (2018, n.p.) explains, "in other words, unequal education opportunities aside, even when two workers do the same job, subcontracting arrangements licitly categorize, schedule, and pay workers according to their nationality, a categorization that often maps too neatly onto race." When salary is determined by nationality, not qualifications or capability, we need to examine more carefully and deeply the connection between race and inequality. As Appel notes (2018, n.p.; emphasis in original), 
Critical approaches to capitalism often argue that markets exacerbate inequality. By contrast, my research with US oil companies in Equatorial Guinea shows that markets are in fact made by that inequality. Global markets, the oil market chief among them, do not merely deepen racialized and gendered postcolonial disparities, they are constituted by them.

Wage inequality along racial lines has little to do with racial differentiation or cultural differences; rather, it is a direct result of racialized inequality originating in colonialism. "The market is not taking advantage of these circumstances; it is constituted by them," Appel writes. What constitutes the intra-migrant economy in the case of Chinese restaurants in South Africa is the ability of Chinese owners to avoid hiring South Africans and to maximize profits from cheap labourers, and the ability of Zimbabweans to easily obtain jobs without proper documentation or skills. In other words, although the precarity they face might be different, inequality and insecurity are the reasons an intra-migrant economy exists in the first place.

The intra-migrant economy is not new, especially in countries of immigrants such as the US and Canada. In today's era of migration and globalization, perhaps more than ever we need more ethnographic projects to explore relations between migration and the intersections of race, gender, and class. My hope is that this ethnographic study case in South Africa, along with Appel's argument, will help us to move beyond racial differentiation and to shine the light on hidden social inequalities, as this kind of interdependence is often built on exploitation and precarity. The lens of the intra-migrant economy offers ways to understand how certain diasporic groups have been positioned in a host country, including what their racial/ethnic and national relationships with the host society are, and what economic and political structures in the host country shape the underlying conditions that create economic differentiation between different migrant groups. The intra-migrant economy speaks of class differences, the world economic hierarchy that exists along racial lines, and how that has affected migration and livelihoods. It is precisely through reflection on migrants' political and economic relations to the host country that we can help build on existing theories and shed new light on the dynamics of social inequality.

\section{Acknowledgements}

I would like to thank the Department of Sociology and Anthropology and the Institute of African Studies at Carleton University, as well as the Department of Anthropology and Development Studies at the University of Johannesburg, for their faculty support. Carleton's Migration and Diaspora Studies and the Social Sciences and Humanities Research Council of Canada were both generous with funding. Gratitude is also extended to Dr. 
Blair Rutherford and three anonymous reviewers for their valuable comments, criticisms, and suggestions.

\section{References}

Appel, H. (2012). Walls and white elephants: Oil extraction, responsibility, and infrastructural violence in Equatorial Guinea. Ethnography, 13(4), 439-465.

Appel, H. (2018, December 18). Race makes markets: Subcontracting in the transnational oil industry. Items: Insights from the Social Sciences. Social Science Research Council. Retrieved from https://items.ssrc.org/race-capitalism/race-makes-marketssubcontracting-in-the-transnational-oil-industry/

BBC Reality Check Team. (2017, December 3). Reality check: Are 90\% of Zimbabweans unemployed? BBC News. Retrieved from https://www.bbc.com/news/business-42116932

Chen, F. L. (2013). Nánfêi zhōngguó xīn yímín yánjiū [New Chinese immigrants in south Africa] (Unpublished doctoral dissertation). Xiamen University, China.

Chikanda, A., \& Dodson, B. (2013). Bandaid transnationalism: Remittance practices of emigrant Zimbabwean medical doctors. Migration \& Development, 2(1), 57-73.

Crush, J., \& Tevera, D. (2010). Exiting Zimbabwe. In J. Crush \& D. Tevera (Eds.), Zimbabwe's Exodus: Crisis, Migration, Survival (pp. 1-49). Cape Town, SA: Unity Press.

Chu, J. (2010). Cosmologies of credit: Transnational mobility and the politics of destination in China. Durham, NC: Duke University Press.

Gous, N. (2017, October 24). The 30 police stations where the most crime was reported. The Times Live. Retrieved from https://www.timeslive.co.za/news/south-africa/2017-10-24the-30-police-stations-where-the-most-crime-was-reported/

Gradin, C. (2013). Race, poverty and deprivation in South Africa. Journal of African Economies, 22(2), 187-238.

Harrison, P., Moyo, K., \& Yang, Y. (2012). Strategy and tactics: Chinese immigrants and diasporic spaces in Johannesburg, South Africa. Journal of Southern African Studies, 38(4), 899-925.

Kuo, L. (2017, April 30). Chinese migrants have changed the face of South Africa. Now they're leaving. Quartz Africa. Retrieved from https://qz.com/940619/chinese-traderschanged-south-africa-now-theyre-leaving/

Liu, Y. Y. T. (2017). Exploring Guanxi in a cross-cultural context: The case of Cantonesespeaking Chinese in Johannesburg. Journal of Chinese Overseas, 13(2), 263-286.

Liu, Y. Y. T. (2018). (Mis)communicating through conflicts: Chinese restaurant owners and Zimbabwean employees in Johannesburg. Africa Journal of Management, 4(4), 426-446.

Makichi, T. (2018, May 23). Unemployment rate at 6,6 percent - Zimstat Survey. Business Times. Retrieved from https://businesstimes.co.zw/unemployment-rate-at-66-percentzimstat-survey/

Makina, D. (2010). Zimbabwe in Johannesburg. In J. Crush \& D. Tevera (Eds.), Zimbabwe's exodus: Crisis, migration, survival (pp. 225-243). Cape Town, SA: Unity Press.

Moyo, K. (2017). Zimbabweans in Johannesburg, South Africa: Space, movement and spatial identity (Unpublished doctoral dissertation). University of the Witwatersrand, Johannesburg, South Africa.

Ong, A. (1987). Spirits of resistance and capitalist discipline: Factory women in Malaysia. New York: State University of New York Press.

Park, Y. J. (2009). Recent Chinese migrations to South Africa: New intersections of race, class and ethnicity. In T. Rahimy (Ed.), Representation, expression and identity: Interdisciplinary insights on multiculturalism, conflict and belonging (pp. 153-168). Oxford: Inter-Disciplinary Press.

Park, Y. J., \& Chen, A. Y. (2009). Recent Chinese migrants in small Ttwns of post-apartheid South Africa. Revue Européenne des Migrations Internationales, 25(1), 25-44.

Silverman, M., \& Zack, T. (2008). House delivery, the urban crisis and xenophobia. In S. Hassim, T. Kupe \& E. Worby (Eds.), Go odme or Die here: Violence, xenophobia and 
the reinvention of difference in South Africa (pp. 147-160). Johannesburg, SA: Wits University Press.

Siu, P. (1987). The Chinese laundryman: A study of social isolation. New York: New York University Press.

Smart, A., \& Smart, J. (2005). Introduction. In A. Smart \& J. Smart (Eds.), Petty capitalists and globalization: Flexibility, entrepreneurship, and economic development (pp. 1-22). Albany, NY: State University of New York Press.

Smart, J. (2003). Ethnic entrepreneurship, transmigration, and social integration: An ethnographic study of Chinese restaurant owners in rural western Canada." Urban Anthropology, 32(3-4), 311-342.

Smith, D. (2015, May 11). Johannesburg's Ponte City: 'The tallest and grandest urban slum in the world'. The Guardian. Retrieved from https://www.theguardian.com/cities/2015/may/11/johannesburgs-ponte-city-the-tallestand-grandest-urban-slum-in-the-world-a-history-of-cities-in-50-buildings-day-33

Statistics South Africa. (2017). Living conditions of households in South Africa: An analysis of household expenditure and income data using the LCS 2014/2015 [Data file]. Retrieved from http://www.statssa.gov.za/publications/P0310/P03102014.pdf

Song, F. (2015 May 6). 非法劳工渐成南非华商的“不定时炸弹’和“负资产 (Illegal workers gradually become 'time bombs' and 'negative assets' of Chinese businessmen in South Africa). People's Daily Online. Retrieved from http://world.people.com.cn/n/2015/0506/c157278-26954005.html

Xiang, B. (2017, April 30). 專訪人類學家項挆風（上）：我們應該「認命」但不能「認輸」 (Interview with anthropologist Xiang Biao (part one): We should 'accept fate' but we cannot 'concede') 端傳媒 Initium Media. Retrieved from https://theinitium.com/article/20170430-opinion-xiangbiao/

$\mathrm{Xu}$, L. (2017). Cyrildene Chinatown, suburban settlement, and ethnic economy in postapartheid Johannesburg. In Young-Chan Kim (Ed.), China and Africa: A new paradigm of global business (pp. 81-104). Cham, CH: Palgrave Macmillan.

van der Berg, S. (2011). Current poverty and income distribution in the context of South African history." Economic History of Developing Regions, 26(1), 120-140.

Yap, M., \& Leong Man, D. (1996). Colour, confusion and concessions: The history of the Chinese in South Africa. Hong Kong: Hong Kong University Press. 